Kinga Białek (D) https://orcid.org/0000-0001-5164-9502

Szkoła Edukacji Polsko-Amerykańskiej Fundacji Wolności

i Uniwersytetu Warszawskiego

k.bialek@szkolaedukacji.pl

\title{
Umiejętność krytycznego czytania jako odpowiedź na wyzwania XXI wieku
}

\author{
The Skill of Critical Thinking as an Answer to the Challenges of the Twenty-First \\ Century
}

\begin{abstract}
The article presents the development of critical reading skills in relation to argumentative texts. This issue is considered on three levels: global trends, challenges of the Polish education system, and activities undertaken in the classroom. Educational activities are considered in the context of the organization of the education system and its place in the social structure, of the specific material presented during lessons, and of character-building activities. Didactic suggestions presented in this paper are rooted in the belief that supporting the cognitive autonomy of students and their proactive attitude requires the school (both as a system and as a learning community) to equip them with the necessary tools and competences. A description of the global educational challenges - including those related to social inequality and its consequences - sets the context for this proposal. In the Polish case, bringing the school experience closer to the world known to students remains one of the primary obstacles. This article proposes a possible solution to this problem through the inclusion of argumentative texts in lessons, the understanding of which requires complex reading and cultural competences. The article presents a proposal on how to develop these skills.
\end{abstract}

Keywords: argumentation, critical reading, reading competence

Streszczenie: Artykuł przedstawia kształcenie umiejętności krytycznego czytania w odniesieniu do tekstów o charakterze argumentacyjnym. Kwestię tę ujęto na trzech płaszczyznach: tendencjach globalnych, wyzwaniach polskiego systemu edukacji oraz działaniach podejmowanych w klasie szkolnej. Działania edukacyjne rozpatrywane są w zakresie organizacji systemu edukacji i jego miejsca w strukturze społecznej, szczegółowych treści omawianych na lekcjach i działań wychowawczych. Przytoczone propozycje dydaktyczne odnoszą się także do przekonania, że wspieranie autonomii poznawczej uczniów i ich postawy proaktywnej wymaga od szkoły (jako systemu i jako wspólnoty uczącej się) wyposażenia ich w niezbędne narzędzia i kompetencje. Kontekstem dla propozycji jest opis globalnych wyzwań edukacyjnych - w tym związanych z nierównościami społecznymi i ich konsekwencjami. 
W polskiej rzeczywistości jednym z największych wyzwań pozostaje zbliżenie szkoły do świata bliskiemu uczniom. W artykule zaproponowano możliwą odpowiedź, jaką jest włączanie do lekcji tekstów argumentacyjnych, których zrozumienie wymaga złożonych kompetencji czytelniczych i kulturowych. W artykule przedstawiono propozycję sposobów kształcenia tych umiejętności.

Słowa kluczowe: argumentacja, czytanie krytyczne, kompetencje odbiorcze

\section{Wstęp}

Niniejszy artykuł omawia tak ważny, choć często zaniedbywany element edukacji polonistycznej w szkole, jakim jest kształcenie umiejętności krytycznego czytania w odniesieniu do tekstów nieliterackich, a w szczególności tekstów o charakterze argumentacyjnym.

Edukacja polonistyczna w szkołach opiera się na kilku istotnych obszarach, które w ogólny sposób opisuje i wydziela podstawa programowa. W najnowszym jej brzmieniu, wprowadzanym do szkół od roku 2017, obszary te nazwano: kształceniem literackim i kulturowym, kształceniem językowym, tworzeniem wypowiedzi, samokształceniem. Z jednej strony granice między tymi obszarami nie mogą być precyzyjnie określone, ponieważ większość kompetencji kształconych na lekcjach języka polskiego musi się odnosić do więcej niż jednej dziedziny. Wystarczy prosty przykład: nie można tworzyć wypowiedzi bez umiejętności związanych z nauką o języku. Jednak dokument prawny, jakim jest podstawa programowa, z zasady opisuje złożoną rzeczywistość edukacyjną w sposób zwięzły i musi ją porządkować, nawet jeśli ten porządek ma charakter arbitralny. Z drugiej strony praktyka nauczycielska pokazuje, że są obszary, które w naturalny sposób łączą się ze sobą, inne - najczęściej pozostają oddzielone. Dlatego bardziej przekonuje mnie podział na odbiór, analizę i interpretację oraz tworzenie tekstów zastosowany w starej, obowiązującej od 2008 roku, podstawie programowej ${ }^{1}$. Moje rozważania dotyczyć będą tego pierwszego obszaru, czyli kompetencji odbiorczych uczniów, które chciałabym przedstawić w szerszym kontekście globalnych i krajowych zjawisk o charakterze społeczno-politycznym. Spojrzenie na tę kwestię wymaga postawienia kilku istotnych założeń.

Pierwsze odnosi się do przekonania, że omówienie działań podejmowanych w szkole należy rozpatrywać holistycznie - zarówno w zakresie organizacji systemu edukacji i jego miejsca w strukturze społecznej, szczegółowych treści omawianych na lekcjach, jak i działań wychowawczych podejmowanych na rzecz społeczności uczącej się. Na postawy i zachowania uczniów, prezentowane

1 Por. Podstawa programowa $z$ komentarzami. Tom 2. Jezyk polski w szkole podstawowej, gimnazjum i liceum, Warszawa 2009. 
także w sytuacjach pozaszkolnych, mają wpływ nie tylko bezpośrednie działania wychowawcze, takie jak realizacja programu wychowawczego lub tworzenie systemu ocen z zachowania, ale także pośrednie formy. Tutaj mam na myśli budowanie pozytywnej atmosfery uczenia się oraz stosowanie metod wspierających współpracę i autonomię poznawczą uczniów. Lekcje języka polskiego wydają się szczególnie predestynowane do pełnienia funkcji formacyjnej - uczniowie na zajęciach poznają bowiem światy emocji innych ludzi poprzez teksty, są twórcami i myślicielami jako autorzy wypowiedzi, uczestniczą w dyskusjach, podejmują próbę zrozumienia świata dzięki interpretacji. To nakłada na nauczycieli odpowiedzialność nie tylko za przekazanie uczniom wiedzy, ale także za rozumienie szerszego kontekstu i celów społecznych realizowanych przez uczenie języka polskiego.

Drugie założenie wynika z popartego badaniami stanowiska mówiącego o tym, że czas spędzony w szkole ma kluczowe znaczenie dla dalszego życia uczniów i uczennic jako członków społeczeństwa. To oznacza, że szkoła powinna się stać dla młodzieży laboratorium prawdziwego życia, miejscem negocjowania i wypracowywania społecznego konsensusu, szkołą demokracji obywatelskiej. Najmniejsze nawet działania podejmowane w szkołach powinny prowadzić do tego, by uczniowie zyskiwali poczucie sprawstwa w rzeczach ich dotyczących, a także przekonanie, że działanie na rzecz wspólnoty ma sens.

Wreszcie, wydaje mi się niezwykle ważne wypowiedzenie stanowiska etyczno-aksjologicznego, które kierunkuje moje myślenie o edukacji, a mianowicie hasła: „Wolność nie może istnieć bez wiedzy i kompetencji” - wspieranie autonomii poznawczej uczniów i kształtowanie ich postawy proaktywnej wymagają od szkoły (jako systemu i jako wspólnoty uczącej się) wyposażenia ich w niezbędne narzędzia. Wszystkie proponowane w dalszej części artykułu rozwiązania odnoszą się do powyższych założeń i z nich wynikają.

Kolejne fragmenty tekstu, zatytułowane „Wyzwania dla świata”, „Wyzwania dla szkoły” i „Wyzwania dla polonistów”, pozwolą mi pokazać perspektywę omawiania zjawiska: od spojrzenia globalnego poprzez problematykę związaną z polskim systemem edukacji aż po postulaty do wdrożenia w klasach szkolnych na lekcjach polskiego.

\section{Wyzwania dla świata}

Najnowsze badania społeczne, zarówno z dziedziny socjologii, jak i psychologii społecznej i ekonomii, wskazują wiele wyzwań stojących przed światem w trzeciej dekadzie XXI wieku. W zeszłym roku World Economic Forum na swoich stronach umieściło raport na temat tego, jakie największe zagrożenia 
czekają świat Anno Domini 2019². Za najważniejsze tendencje uznano klęskę działań na rzecz klimatu, wymuszone migracje na ogromną skalę oraz głęboką niestabilność społeczną. Wszystkie te zagrożenia globalne są ze sobą połączone i wzajemnie się potęgują. Wśród nich autorzy opracowania wyróżniają konsekwencje ekonomiczne (na przykład brak dostępu do środków i inflację), polityczne (na przykład kryzys zaufania do władzy państwowej lub nieskuteczność działań podejmowanych przez państwa) i społeczno-kulturowe (narażanie się na cyberataki lub rozpad tradycyjnych mediów informacyjnych). Mimo upływu czasu, od ogłoszenia tych postulatów minął prawie rok, nie wydaje się, aby straciły na aktualności. Międzynarodowe organizacje państwowe nie mają wystarczającej siły sprawczej, by przeciwdziałać postępującym problemom współczesnego świata.

Jednym z nich jest niewątpliwie rozwarstwienie społeczne. Ma ono oczywiste konsekwencje dla światowej gospodarki, ale nie tylko. Z nierównościami ekonomicznymi wiążą się nierówności społeczne, takie jak ograniczenie najmniej uposażonym grupom dostępu do podstawowych zdobyczy cywilizacyjnych, wśród nich edukacji o wysokiej jakości. Autorzy opublikowanego kilka lat temu opracowania Duch równości, Kate Pickett i Richard Wilkinson, a za nimi ekonomista Anthony B. Atkinson, wykazują bezpośredni wpływ nierówności między innymi na takie dziedziny życia, jak zdrowie fizyczne i psychiczne, uzależnienia, aktywność społeczna i obywatelska, a także wyniki nauczania ${ }^{3}$. Przy czym, jak stwierdzili badacze analizujący dane statystyczne i demograficzne, to właśnie skala nierówności miała decydujący wpływ na występowanie problemów społecznych, bardziej niż sama średnia wysokość dochodu w danym kraju. Jak piszą Pickett i Wilkinson: „Dobrostan i poczucie szczęścia ludzi przestały wzrastać wraz ze wzrostem gospodarczym. Zamożne społeczeństwa, wciąż coraz bardziej się bogacąc, są coraz bardziej nękane lękiem, depresją i innymi problemami. Populacje krajów bogatych dotarły do kresu historycznej wędrówki”“"

W niniejszym tekście najbardziej skupiać się będę na implikacjach dotykających szkoły i szeroko pojętej edukacji. Mimo szczególnej troski, jaką różne organizacje międzynarodowe otaczają systemy edukacyjne w krajach rozwijających się, nie udaje się wyrównać szans uczniów pochodzących z różnych środowisk, a także z różnych krajów. W dobie gwałtownej globalizacji okazuje się, że strategie izolacjonistyczne stosowane przez kraje bogatsze nie prowadzą do ograniczenia oddziaływania na nie trudności krajów rozwijających się, dlatego tym mocniej podkreśla się wartość wspólnych działań podejmowanych na

2 Por. The Global Risks Report 2019. $14^{\text {th }}$ Edition, http://www3.weforum.org/docs/WEF_ Global_Risks_Report_2019.pdf, dostęp: 9.11.2019.

3 Por. A.B. Atkinson, Nierówności. Co da się zrobic?, tłum. M. Ratajczak, M. Szlinder, Warszawa 2017; R. Wilkinson, K. Pickett, Duch równości. Tam gdzie panuje równość wszystkim żyje się lepiej, tłum. P. Listwan, Warszawa 2011.

4 R. Wilkinson, K. Pickett, dz. cyt., s. 22. 
rzecz walki z nierównościami. W ciąż największy wpływ na osiągnięcia szkolne oraz na sam wybór szkoły i liczbę lat poświęcanych na edukację ma środowisko rodzinne. Również postawy wobec edukacji zmieniają się w zależności od uposażenia i poziomu wykształcenia rodziców. Samo istnienie tego zjawiska wydaje się zupełnie oczywiste, jednak niepokojąca jest skala wpływu, zwłaszcza w krajach, w których powszechna edukacja istnieje od dziesięcioleci.

Mniej oczywisty wniosek z cytowanych przeze mnie opracowań dotyczy powiązania pomiędzy dostępem do edukacji wysokiej jakości a funkcjonowaniem w świecie nowoczesnych mediów. Dobra edukacja zapewnia (a przynajmniej zapewniać powinna) młodym ludziom narzędzia pomocne w analizie i interpretacji rzeczywistości, która ich otacza, a nie jest to rzeczywistość prosta. Obserwujemy bowiem tworzenie się globalnej kultury masowej opartej na paradoksalnym zjawisku pozornego dostępu do informacji. Z jednej strony obywatele świata dzięki internetowi mają dostęp do różnych danych, z drugiej - przytłaczająca ilość tych danych wymaga od użytkowników zdobywania coraz to nowych umiejętności ich selekcji i krytycznej oceny. W społeczeństwie globalnej wioski, o której pisał Herbert Marshall McLuhan', szybciej niż kiedykolwiek wcześniej rozprzestrzeniają się zjawiska manipulowania informacjami, ich dystrybucją i dostępnością. Te zjawiska wykorzystują przede wszystkim niedostateczny poziom kompetencji użytkowników sieci, a on z kolei wynika z jakości edukacji.

W swoim tekście nie omówię szczegółowo wszystkich zjawisk związanych z niebezpieczeństwami czyhającymi na członków społeczeństwa informacyjnego. Skupię się na tych, które w oczywisty sposób muszą wpływać na kształcenie polonistyczne. Zacznę od zjawiska, które w ostatnich latach miało decydujący wpływ na politykę i społeczeństwo, a mianowicie od postprawdy i fake newsów. Mathew d'Ancona, nagradzany brytyjski dziennikarz i obserwator życia politycznego, w swojej książce Postprawda tak pisze o tym zjawisku:

Sednem tej globalnej tendencji jest krach wartości prawdy, porównywalny do załamania waluty czy kursu akcji. Uczciwość i rzetelność nie mają już priorytetu w politycznych transakcjach. (...) Internetowe strony zwolenników teorii spiskowych gardzą prasą drukowaną czy też mediami głównego nurtu jako skompromitowanym głosem globalistycznego porządku czy liberalnej elity, której czas zwyczajnie minął. Ekspertów szkaluje się jako złowrogi kartel, a nie źródło weryfikowalnej informacji. Miej odwagę korzystać ze swego rozumu było Kantowską propozycją oświeceniowego motta. Dzisiejszy odpowiednik głosiłby: Odważ się z niego nie korzy$s t a c^{6}$.

5 Por. H.M. McLuhan, Galaktyka Gutenberga, tłum. A. Wojtasik, Warszawa 2017.

6 M. d'Ancona, Postprawda, tłum. M. Sutowski, Warszawa 2018, s. 18. 
Ta diagnoza ma swoje oczywiste konsekwencje także w innym zjawisku. Obserwujemy, również w Polsce, niepokojącą tendencję przesuwania idei i faktów ze sfery obiektywnej prawdy do sfery społecznych negocjacji. Przykłady można mnożyć, ale wśród tych najbardziej aktualnych jest debata na temat zmian klimatycznych - pomimo istniejącej w środowiskach naukowych zgody co do wpływu działalności człowieka na klimat wciąż przyjmuje się jako równoważne tezy przeciwne. Prowadzi to do niesłusznych wniosków przebijających się do opinii publicznej, jakoby w środowisku naukowym trwała dyskusja między różnymi, nie dość jeszcze udowodnionymi stanowiskami. Podobnie rzecz się ma z siłą oddziaływania ruchów antyszczepionkowych. W tym wypadku możemy potraktować to zjawisko jako pewien model. Ruch czerpie inspirację z wielokrotnie dezawuowanych i podważanych badań pseudonaukowych. Sam ich autor wycofał się z głoszonych przez siebie tez. A jednak zwolennicy ruchu, mimo prowadzonych przez naukowców akcji informacyjnych, odmawiają szczepień dzieci, tłumacząc się strachem przed skutkami ubocznymi. Oficjalne stanowiska naukowców są przez członków ruchu podważane z powodu ich domniemanych związków z korporacjami farmaceutycznymi. Działania na poziomie polityki państwowej wspierające programy szczepień obowiązkowych są ignorowane, a ów „ruch obywatelskiego nieposłuszeństwa” tłumaczy się prawem do wolności w wychowaniu dzieci zgodnie z własnym światopoglądem. W ten sposób zrównuje się subiektywne, niefalsyfikowane przekonania jakiejś grupy społecznej z obiektywną, twardą i opartą na badaniach wiedzą naukową i tym pierwszym próbuje się nadać status prawa.

Przekonania różnych grup społecznych wzmacniane są przez oddziaływanie nowych źródeł wiedzy, jakimi dla współczesnych społeczeństw są media społecznościowe. Cechą charakterystyczną tych portali komunikacyjnych jest skrajna "demokratyzacja” debaty i rozproszenie autorstwa: na Twitterze czy Facebooku opinia naukowca czy badacza jest równie ważna jak głos zwolennika teorii spiskowych, a miarą jakości staje się popularność mierzona przez liczbę obserwatorów i polubień. Ten system wymiany myśli nie sprzyja pogłębieniu dyskusji merytorycznej - potencjalni jej uczestnicy na przykład na Facebooku najczęściej ograniczają się do prostej emotikonowej reakcji. Tym bardziej że algorytmy podsuwają im propozycje bliskie ich własnym poglądom, pogłębiając zjawisko bańki informacyjnej.

Warto podkreślić ponownie mało oczywisty związek między skalą tych zjawisk a opisanymi wcześniej nierównościami w dostępie do edukacji wysokiej jakości. W świecie dominacji cyfrowej społeczność międzynarodowa musi zadbać o szkolnictwo publiczne, bo szkoła to naturalne środowisko mogące wyrównywać szanse wszystkich dzieci, niezależnie od statusu społeczno-ekonomicznego ich rodziców. 


\section{Wyzwania dla szkoły}

W opracowanych przez Komisję Europejską dokumentach dotyczących wspólnej polityki edukacyjnej podkreśla się obszary, które wymagają szczególnej troski zarówno decydentów politycznych, jak i placówek wdrażających zmiany w życie, takich jak integrowanie migrantów i uchodźców ze społeczeństwami Europy, wspieranie tworzenia inkluzyjnego społeczeństwa, przyjaznego dla mniejszości, i zwiększanie mobilności społecznej obywateli ${ }^{7}$. Wszystkie te obszary wymagają od szkół wypracowania takich strategii, które najlepiej wspierają uczniów i uczennice w przygotowaniu się do świadomego uczestnictwa w kulturze i życiu społecznym.

Szkoła nie może abstrahować ani od otaczającej ją rzeczywistości społecznej, ani od zjawisk współczesnej kultury. W trakcie edukacji uczniowie muszą mierzyć się z prawdziwymi wyzwaniami, jak najbliższymi ich doświadczeniu. Szkoła musi się stać „laboratorium życia społecznego”, a także powinna wyposażyć swoich podopiecznych w narzędzia służące elastycznemu dostosowaniu się do zmiennych warunków, wiele lat po jej ukończeniu, zgodnie z postulatami „uczenia się przez całe życie”.

Twórcy obowiązującej podstawy programowej dla szkoły podstawowej zdają się w pełni świadomi tych uwarunkowań. W preambule do dokumentu możemy przeczytać:

Najważniejsze umiejętności rozwijane w ramach kształcenia ogólnego w szkole podstawowej to:

1) sprawne komunikowanie się w języku polskim oraz w językach obcych nowożytnych;

2) sprawne wykorzystywanie narzędzi matematyki w życiu codziennym, a także kształcenie myślenia matematycznego;

3) poszukiwanie, porządkowanie, krytyczna analiza oraz wykorzystanie informacji z różnych źródeł;

4) kreatywne rozwiązywanie problemów z różnych dziedzin ze świadomym wykorzystaniem metod i narzędzi wywodzących się z informatyki, w tym programowanie;

5) rozwiązywanie problemów, również z wykorzystaniem technik mediacyjnych;

6) praca w zespole i społeczna aktywność;

7) aktywny udział w życiu kulturalnym szkoły, środowiska lokalnego oraz kraju .

7 Por. EUSupport for School Policy, https://ec.europa.eu/education/policies/school/about-school-policy_en, dostęp: 9.11.2019.

8 Podstawa programowa ksztatcenia ogólnego z komentarzem. Szkoła podstawowa. Język polski, s. 5-6, https://www.ore.edu.pl/2017/12/ppko/, dostęp: 9.11.2019. 
$\mathrm{Na}$ poziomie deklaracji programowych wydaje się, że udało się osiągnąć konsensus i wszyscy projektujący system edukacji zgadzają się co do jej najważniejszych celów. Jednak rzeczywistość nie potwierdza, że cele te są realizowane w wystarczający sposób. Tym bardziej że ocena poziomu umiejętności polskich uczniów, jakkolwiek wysoka w porównaniu z innymi krajami, wciąż pozostawia przestrzeń do poprawy.

Jednym z najbardziej wiarygodnych źródeł informacji na temat umiejętności polskich uczniów jest badanie międzynarodowe PISA. Od pierwszej edycji badania w Polsce w roku 2000 obserwuje się znaczący wzrost wyników nastolatków. Od roku 2006 nasz kraj znajduje się w czołówce państw o najwyższych wynikach. Po opublikowaniu wyników badania z roku 2018 wiemy, że trend związany z wysokimi osiągnięciami uczniów w zakresie czytania został zachowany - średni rezultat polskich gimnazjalistów to 512 punktów (średnia krajów OECD - 487 punktów). A jednak, nawet przy świadomości tego, jak dobrze w ogólnym zestawieniu radzą sobie polscy uczniowie, należy spojrzeć krytycznie na ich wyniki. Autorzy raportu z poprzedniej edycji badania PISA 2015 w części czytanie, Krzysztof Biedrzycki i Piotr Bordzoł, piszą:

Najwięcej zadań należało do obszaru interpretacji. Są to zadania znacznie trudniejsze niż w obszarze wyszukiwania informacji, wobec czego wyniki w oczywisty sposób okazują się słabsze. Istotne jest jednak ich porównanie z wynikami innych krajów i z wynikami z poprzednich edycji badania PISA w Polsce. Otóż w przypadku większości zadań z tego obszaru polskie rezultaty są lepsze niż przeciętne w OECD, ale przeważnie gorsze niż w krajach osiągających najwyższe lokaty (jak Finlandia, Irlandia czy Estonia). W tym obszarze nastąpił też najbardziej widoczny spadek wyników. (...) Największą trudność dla polskich uczniów stanowią zadania, w których trzeba się wykazać wnikliwością interpretacyjną, samodzielnością myślenia i umiejętnością zwięzłego sformułowania myśli (są to często zadania otwarte) ${ }^{9}$.

Te umiejętności, które uznane są za kluczowe, takie jak krytyczne myślenie, wciąż stanowią wyzwanie dla polskich nastolatków. Wyniki badania z roku 2018 nie ujawnią jeszcze oddziaływania obecnej podstawy programowej (w ostatniej edycji badano uczniów ostatniego rocznika gimnazjum) - nie wiemy zatem, w jakim stopniu wpłynie ona na jakość kształcenia w tych obszarach.

Tymczasem właśnie to działania szkół i nauczycieli mogą znacząco wpłynąć na poziom kompetencji przyszłych członków społeczeństwa. W zestawieniu z opisywanymi wcześniej praktykami funkcjonowania w społeczeństwie sieci szkoła jest naturalnym czynnikiem zmniejszającym poziom niekompetencji

9 K. Biedrzycki, P. Bordzoł, Czytanie i interpretacja [w:] Program Międzynarodowej Oceny Umiejętności Uczniów. Wyniki badania PISA 2015 w Polsce, red. M. Federowicz, M. Sitek, Warszawa 2017, s. 67. 
użytkowników i może zmniejszyć siłę oddziaływania postprawd. To z kolei może się przełożyć na ogólny społeczny wzrost świadomości odbiorców kultury.

\section{Wyzwania dla polonistów}

W jaki sposób szkolni poloniści mogą reagować na zdiagnozowane przeze mnie wyzwania? $\mathrm{Na}$ to pytanie możliwe jest wiele różnych, często równie sensownych i prawdziwych odpowiedzi. W swoim tekście pragnę zwrócić uwagę na aspekt edukacji polonistycznej związany z włączaniem do lekcji tekstów nieliterackich, argumentacyjnych, których zrozumienie wymaga złożonych kompetencji czytelniczych i kulturowych. W tej części artykułu przedstawię moją propozycję sposobów kształcenia tych umiejętności, podkreślając ich wagę dla budowania społeczeństwa obywatelskiego przyszłości. Wydaje mi się, że istnieją w praktyce dydaktycznej od dawna obecne rozwiązania, które jednak wymagają modyfikacji, by stały się rzeczywiście skuteczne.

W latach 2017-2018 wraz z Magdaleną Swat-Pawlicką przeprowadziłyśmy kwerendę podręczników szkolnych do gimnazjum, wybrałyśmy do badania trzy najbardziej popularne serie („Między nami”, „Słowa na czasie” oraz „Świat w słowach i obrazach”), które mają swoją kontynuację w obecnej, zreformowanej szkole podstawowej. Ja przeanalizowałam ich zawartość pod kątem liczby i jakości tekstów nieliterackich i towarzyszących im zadań dla uczniów ${ }^{10}$. Podręczniki szkolne zawierały różne teksty, jednak zdecydowanie najczęściej kryterium ich doboru był temat. Konsekwencją takiego ułożenia jest brak hierarchicznego narastania trudności. Potwierdzają to także zadania dla uczniów, najczęściej wymagające wykorzystania prostych umiejętności (na niższych poziomach taksonomicznych Blooma i Webba ${ }^{11}$ ). Najrzadziej proponowano uczniom zadania wymagające badania struktury tekstu, a zamieszczone w podręcznikach zadania analityczne związane z warstwą językową nie prowadzily do wniosków o charakterze interpretacyjnym. Autorzy nie zamieszczali także

10 Opracowanie zamieszczone w mojej rozprawie doktorskiej Ksztatcenie umiejętności odbiorczych uczniów w wieku 13-15 lat w odniesieniu do tekstów argumentacyjnych, obecnie w trakcie publikacji.

11 Termin taksonomia celów nauczania odnosi się do takiego ich ujęcia, w którym pokazuje się ich hierarchię i zorganizowanie pod względem stopnia komplikacji. W 1956 roku taką taksonomię celów edukacyjnych opracował Benjamin Bloom wraz z zespołem (B.S. Bloom, M.D. Engelhart, E.J. Furst, W.H. Hill, D.R. Krathwohl, Taxonomy of Educational Objectives: The Classification of Educational Goals. Handbook I: Cognitive Domain, New York 1956), wskazując sześć poziomów celów poznawczych: wiedza, rozumienie, zastosowanie, analiza, synteza, ewaluacja. Innym ujęciem jest stworzony przez Normana Webba w 1997 roku system poziomów głębokości wiedzy (DOK): recall \& reproduction, skills \& concepts, strategic thinking, extended thinking (N.L. Webb, Criteria for Alignment and Assessment of Expectations in Mathematics and Science Education, „Research Monograph” 1997, nr 6). 
propozycji uniwersalnej procedury pracy z tekstem, zakładano, że uczniowie po prostu będą odpowiadać na kolejne pytania.

Warto się zastanowić nad konsekwencjami takiej praktyki. O ile dzięki omawianiu na lekcji różnych ciekawych tekstów i tematów uczniowie mają szansę spotkać się z ciekawymi zagadnieniami, o tyle takie lekcje nie będą służyć wyposażeniu ich w uniwersalne narzędzia przydatne do radzenia sobie w sytuacjach pozaszkolnych. Dotyka to najmocniej tych uczniów, którzy wiedzę i umiejętności czerpią wyłącznie ze szkoły - pochodzących ze środowisk mniej uposażonych, którzy nie funkcjonują w głównym nurcie kultury. Dla nich szczególnie szkoła powinna zadbać o to, by zapewniać dostęp do tekstów autentycznych, życiowych, pochodzących z różnych źródeł (i mediów tradycyjnych, i elektronicznych). Powinno się także zatroszczyć o to, by zbudować w nich nawyki i postawy na tyle trwałe, by mogli się nimi posługiwać w różnych warunkach. Takimi nawykami będą: uważne, wielokrotne czytanie, częste notowanie, wnioskowanie na podstawie szczegółów w tekście i wreszcie - podawanie w wątpliwość tez autora. Wszystkie one spełnione są w założeniach czytania proceduralnego, którego schemat przedstawię poniżej ${ }^{12}$.

Uczenie się rozumiane jako rozwój i zmiana opiera się na założeniu, że uczniowie w klasie realizują ambitne cele, które wymagają intelektualnego zaangażowania i są dla nich prawdziwą trudnością. Wysokie oczekiwania wobec wszystkich uczniów są jednym z warunków efektywnego nauczania. Wyzwaniem dla uczniów mogą być same teksty, które obrazują jakąś zdefiniowaną trudność, na przykład skomplikowaną i niejednoznaczną strukturę, wymagania na poziomie wiedzy uprzedniej, złożoną budowę językową, i ten problem staje się treścią nauczania. Uczniowie zatem nie tylko czytają tekst na lekcji, ale przede wszystkim nabywają umiejętności radzenia sobie w jakiejś uprzednio zdefiniowanej sytuacji.

Jednak samo stawianie wysokich wymagań nie oznacza, że uczniowie podejmą próbę zrozumienia materiału czy przyswojenia nowej umiejętności. Zadaniem nauczyciela jest pokazanie drogi między realizacją celu a momentem rozwojowym, w jakim znajdują się uczniowie. Takie podejście do uczenia związane jest z konstruktywistyczną koncepcją uczenia się. Stopniowe „uniezależnianie” uczniów, stwarzanie im okazji do coraz bardziej samodzielnych działań, w dydaktyce konstruktywistycznej określane jest terminem scaffolding, czyli najprościej - „budowaniem

12 Czytanie proceduralne to termin wprowadzony przeze mnie jako modyfikacja amerykańskiego pojęcia close reading w znaczeniu metody pracy z tekstem na lekcji. Opisywane w dalszej części artykułu elementy programu dydaktycznego są autorską propozycją opartą na rozwiązaniach amerykańskich. 
rusztowania"13. W metodzie czytania proceduralnego funkcję rusztowania będą pełnić kolejne etapy pracy z tekstem. Najpierw, po pierwszej pobieżnej lekturze, uczniowie czytają samodzielnie tekst ponownie i zajmują się wyszukiwaniem szczegółów na poziomie dosłownym: na przykład znajdują i podkreślają nacechowane emocjonalnie słowa i wyrażenia lub zaznaczają fragmenty dotyczące różnych zjawisk opisanych w tekście. Polecenia przekazuje nauczyciel, a oparte są one na zdefiniowanej wcześniej przez niego dominancie tekstu. Uczniowie pracują samodzielnie, wspierając się wzajemnie w parach, dyskutując i porównując swoje notatki.

Następnym etapem pracy jest szukanie powiązań i wnioskowanie. To etap przygotowujący do syntezy tekstu. W tym czasie uczniowie ponownie czytają tekst i wyszukują w nim na przykład niespójności lub precyzują nazwane na początku pracy założenia na temat głównego tematu tekstu. Ponownie dyskutują też ze sobą, uzgadniając rozumienie. Jak na poprzednim etapie powstają notatki. Ostatnia część pracy związana jest $\mathrm{z}$ interpretacją głównego problemu tekstu. Uczniowie ponownie sprawdzają swoje hipotezy dzięki kolejnej lekturze, szukają dowodów odnoszących się bezpośrednio do tekstu, cytatów i fragmentów. Podejmują również próbę ewaluacji tekstu: zestawieniem z innymi źródłami wiedzy i własnym doświadczeniem życiowym, a także możliwymi konsekwencjami uznania tekstu. Służą temu pytania krytyczne, takie jak: kto mógłby być zadowolony z publikacji tego tekstu? Czyj głos jest pominięty? Jakie są możliwe intencje autora? W czyim imieniu się wypowiada? Jakie wartości reprezentuje tekst? Uczniowie często mają też możliwość pisemnej odpowiedzi na tekst. Proces, jaki przeszli, pracując nad nim, sprawia, że uczniowskie wypowiedzi są bardziej merytoryczne i pogłębione.

Każdy etap pracy wymaga od nauczyciela nazwania zarówno problemów, z jakimi mierzą się czytelnicy, jak i możliwych strategii radzenia sobie z nimi. To ważne, by z sytuacji szkolnej uczynić model dla sytuacji pozaszkolnych - na przykład związanych z czytaniem tekstów w sieci. Uczenie metodą proceduralną ma konsekwencje nie tylko w podniesieniu umiejętności rozumienia tekstu ${ }^{14}$, ale przede wszystkim w wypracowywaniu pewnych trwałych postaw. Najważniejsze w kontekście społecznych wyzwań wydają się uważność, postawa ograniczonego zaufania oraz radzenie sobie z niejednoznacznością. Użytkownicy internetu często nie dość uważnie czytają teksty, z jakimi się spotykają, zamiast czytać, skanują

13 Por. D.J. Wood, J.S. Bruner, G. Ross, The Role of Tutoring in Problem Solving, „Journal of Child Psychiatry and Psychology" 1976, nr 17, s. 89-100.

14 Wyniki metaanalizy w zakresie wzmacniania umiejętności rozumienia tekstu dla strategii close reading w praktyce szkół amerykańskich przedstawiono w raporcie National Reading Panel. Teaching Children to Read: An Evidence-Based Assessment of the Scientific Research Literature on Reading and Its Implications for Reading Instruction. Reports of the Subgroups, Washington, DC 2000. 
je lub ograniczają się do przeczytania nagłówków. Sytuacja, w której na lekcjach regularnie pracują metodą wielokrotnej lektury, może pozytywnie wpłynąć na zmianę tych zachowań. Pogłębiona ewaluacja i weryfikacja tekstu, która jest obowiązkowym elementem metody, może pomóc uczniom nabrać wprawy w szukaniu innych źródeł i zestawianiu ich z informacjami przeczytanymi w sieci. Z kolei świadomość tego, że ważne i kontrowersyjne kwestie rzadko są jednoznaczne, że biorący udział w debacie ludzie reprezentują różne systemy wartości, a co za tym idzie - różne środowiska, i że ma to wpływ na głoszone przez nich tezy, pozwoli zbudować asertywność poznawczą i niechęć do zbyt szybkiego akceptowania sądów innych. Moje przekonanie o tym, że sposoby pracy z tekstami na lekcjach mają wpływ na prezentowane postawy w świecie pozaszkolnym, potwierdza także lektura tekstów Paula Freirego, reprezentującego nurt pedagogiki krytycznej. Jego program wsparcia alfabetyzacji najbiedniejszych środowisk Ameryki Łacińskiej zasadzał się na wzmocnieniu postaw społecznego i obywatelskiego zaangażowania. Obecny w jego tekstach postulat conscientização, co przetłumaczyć można jako „wzmacnianie świadomości krytycznej”, dotyczył właśnie pogłębiania samodzielnego wnioskowania i nieulegania prostym rozwiązaniom ${ }^{15}$.

Efektywność uczenia się zależy także od jeszcze jednego czynnika wzmacniania umiejętności metapoznawczych uczniów ${ }^{16}$. Procedury i strategie pracy z tekstem muszą być omówione tak, aby po jakimś czasie stosowania uczniowie mogli samodzielnie dokonywać ich wyboru w odniesieniu do różnych tekstów. Uczniowie powinni także badać ich efektywność. Służyć temu może obserwowanie i nazywanie swoich reakcji na teksty i uświadamianie sobie tego, w jaki sposób teksty wpływają na ich poglądy i sposób patrzenia na świat.

Czytanie proceduralne to nie tylko konkretne techniki pracy z tekstem. To przede wszystkim postulat zmiany myślenia o projektowaniu procesu

15 Freire tak pisał o świadomości krytycznej: „Krytyczna świadomość charakteryzuje się głębokością interpretacji problemów; zastępowaniem przez rozumowanie przyczynowe wyjaśnień magicznych; sprawdzaniem własnych „ustaleń” i gotowością do ich rewidowania; próbą unikania przekłamań podczas próby zrozumienia problemów i unikania przedsądów podczas ich analizy; odrzuceniem zbywania odpowiedzialności; odrzuceniem postawy biernej; spójnością argumentacji; praktykowaniem dialogu, nie sporów; otwarciem na nowe z przyczyn wykraczających poza samą potrzebę nowości oraz rozumienie, że nie należy odrzucać starego tylko dlatego, że jest stare - akceptowaniem wartości zarówno starego, jak i nowego" P. Freire, Education for Critical Consciousness, London-New York 2005, s. 14 [tłum. własne - K.B.]. Por. też: tenże, Pedagogy of the Oppressed, London-New York 2000.

16 Na skuteczność strategii metapoznawczych w procesie kształcenia uczniów wskazywał między innymi John Hattie, pisząc o znaczącym wpływie na wyniki kształcenia. Por. tenże, Widoczne uczenie się dla nauczycieli. Jak maksymalizować sitę oddziatywania na uczenie się, thum. Z. Janowska, Warszawa 2015. 
uczenia się uczniów. Jest to również sposób na zbliżenie szkoły do globalnej rzeczywistości, jaka nas otacza.

\section{Bibliografia}

d'Ancona M., Postprawda, tłum. M. Sutowski, Warszawa 2018.

Atkinson A.B., Nierówności. Co da się zrobić??, tłum. M. Ratajczak, M. Szlinder, Warszawa 2017.

Białek K., Kształcenie umiejętności odbiorczych uczniów w wieku 13-15 lat w odniesieniu do tekstów argumentacyjnych [w druku].

Biedrzycki K., Bordzoł P., Czytanie i interpretacja [w:] Program Międzynarodowej Oceny Umiejętności Uczniów. Wyniki badania PISA 2015 w Polsce, Warszawa 2017.

Bloom B.S., Engelhart M.D., Furst E.J., Hill W.H., Krathwohl D.R., Taxonomy of Education for All. Global Monitoring Report, UNESCO 2006.

Educational Objectives: The Classification of Educational Goals. Handbook I: Cognitive Domain, New York 1956.

EU Support for School Policy, https://ec.europa.eu/education/policies/school/ about-school-policy_en, dostęp: 9.11.2019.

Freire P., Education for Critical Consciousness, London-New York 2005.

Freire P., Pedagogy of the Opressed, London-New York 2000.

Frey N., Fisher D., Rigorous Reading. 5 Access Points for Comprehending Complex Texts, Thousand Oaks, CA 2013.

The Global Risks Report 2019. $14^{\text {th }}$ Edition, http://www3.weforum.org/docs/WEF_ Global_Risks_Report_2019.pdf, dostęp: 9.11.2019.

Gregory A.E., Cahill M.A., Constructing Critical Literacy: Self-Reflexive Ways for Curriculum and Pedagogy, „Critical Literacy: Theories and Practices” 2009, t. 3 , nr 2 .

Hattie J., Widoczne uczenie się dla nauczycieli. Jak maksymalizować sitę oddziatywania na uczenie się, tłum. Z. Janowska, Warszawa 2015.

Lehman C., Roberts K., Falling in Love with Close Reading, Portsmouth, NH 2014.

Lemov D., Teach Like a Champion, San Francisco 2015.

Luke A., Freebody P., Shaping the Social Practices of Reading [w:] Constructing Critical Literacies: Teaching and Learning Textual Practice, red. S. Muspratt, A. Luke, P. Freebody Cresskill, NJ 1997.

McLuhan H.M., Galaktyka Gutenberga, tłum. A. Wojtasik, Warszawa 2017.

National Reading Panel. Teaching Children to Read: An Evidence-Based Assessment of the Scientific Research Literature on Reading and Its Implications for Reading Instruction. Reports of the Subgroups, Washington, DC 2000.

O’Reilly T., Wang Zuowei, Sabatini J., How Much Knowledge Is Too Little? When a Lack of Knowledge Becomes a Barrier to Comprehension, „Psychological Science" wrzesień 2019, t. 30, nr 9. 
Podstawa programowa ksztatcenia ogólnego z komentarzem. Szkota podstawowa. Jezzyk polski, https://www.ore.edu.pl/2017/12/ppko/, dostęp: 17.10.2019.

Podstawa programowa z komentarzami. Tom 2. Jezyk polski $w$ szkole podstawowej, gimnazjum i liceum, Warszawa 2009.

Shannon P., Progressive Reading Education in America: Teaching Toward Social Justice, New York 2017.

Shannon P., Reading Wide Awake: Politics, Pedagogies and Possibilities, New York 2011.

Webb N.L., Criteria for Alignment and Assessment of Expectations in Mathematics and Science Education, „Research Monograph” 1997, nr 6.

Wilkinson R., Pickett K., Duch równości. Tam gdzie panuje równość wszystkim żyje sięlepiej, tłum. P. Listwan, Warszawa 2011.

Wood D.J., Bruner J.S., Ross G., The Role of Tutoring in Problem Solving, „Journal of Child Psychiatry and Psychology" 1976, nr 17. 